\title{
The Effectiveness of "Mock Barista Room" for Hotel Operation Module at Sungai Petani Community College - A Case Study
}

\author{
Muhd Aminuddin Azizan, Mohd Ariff Fahmi Md Noor, and Reezlin Abd Rahman
}

\begin{abstract}
This survey study was conducted to identify the effectiveness of "Beverages Lab - Mock Barista Room" for Hotel Operation Modul as a teaching and learning innovation towards students learning method at Sungai Petani Community College. The module includes the methods of preparing all kinds of hot and cold beverages for Food and Beverages subject. This innovative teaching and learning approach reveals the real high skills work experience in preparing and serving beverages and coffee. This quantitative study involved the students of Hotel Operation, Sungai Petani Community College as respondents. The data was then analysed using SPSS software Version 21. The descriptive analysis report shows that respondents agreed with the functions of "Mock Barista Room" inproviding a condusive learning experience for them, in which the arrangement and the interior design of the room are aligned with the industrial needs. The findings of the research also reveal that the room is able to enhance students' knowledge, skills and self-confidence.
\end{abstract}

Index Terms-Community college, competency, food and beverage.

\section{INTRODUCTION}

The study aims to investigate the effectiveness of innovation in the preparation and execution of 'Beverages Lab - Mock Barista Room'. The innovation supports and facilitates the students in acquiring the skills and methods in preparing and serving all kinds of hot and cold beverages as stated in the module. It involves the students of Sungai Petani Community College, pursuing Certificate in Hotel Operations. The classroom implements a Bar Counter concept for students' work station thus allowing them to experience a real work environment in food and beverages service industry. Besides, it improves students' skills in preparing all types of coffee beverages and mastering the arts of preparing coffee as well as other hot drinks in a systematic way.

\section{A. Background of the Study}

As there is no accurate and comprehensive teaching method for hotbeverages preparation, it influences the students' performances and proficiency in the subject. This is contrasting to the nature of learning environment at

Manuscript received November 6, 2017; revised January 8, 2018.

The authors are with the Sungai Petani Community College, Malaysia (e-mail: amzizan1986@gmail.com, ariff_kksp@yahoo.com, riezman_kksp@yahoo.com).
Community College that requires a comprehensive approach and sufficient facilities. This is essential for effective learning outcomes that tailors and molds the students according to the industrial needs.

Hence, this had forced the institution to conduct visits to the industries whereby the students could only learn through live tutorial without the hands on activity. However, the importance of hands on activity is supported by [1] in which there are many institutions that focus on equipping individuals, especially the young generation with academic ability through strong skills, strong knowledge and foundation. It is also focusing on practical more than theoretical elements. However, if the method is not applied, it can minimize the effectiveness of learning process as they are only exposed to the educational excursion, industrial visits and video presentation by the lecturers.

In addition to that, the hands on activities for this subject should be implemented because it is now a need in the industry for Barista \& Bartender field. Nowadays, the career of barista and bartender is a trend in food and beverages service. It is also one of the categories competed in the national and international competition.

\section{B. Problem Statement}

The urgent need to be aligned with the requirements of industry has initiated the installation of basic infrastructures for coffee preparation in the room for students' practical experience. As for that, the management of Sungai Petani Community College has agreed to improve the facilities in the room for a better teaching and learning environment of the students. The room is also equipped with a coffee machine as well as latest equipment's contributed from the collaboration with the industry. After a year of implementation, this study was conducted in order to identify its impacts on students' competency.

\section{Research Objectives}

The objective of the survey study is:

1) To explore the perception of students towards their learning experience using mock barista room.

- to examine the effectiveness of the facilities in Mock Barista Room

- to explore the performance of students in term of their knowledge on coffee barista module.

- to explore the performance of students in term of their skills on coffee barista module.

- to explore the performance of students in term of their confidence level on coffee barista module.

D. Research Framework 
TABLE I: THE RESEARCH FRAMEWORK

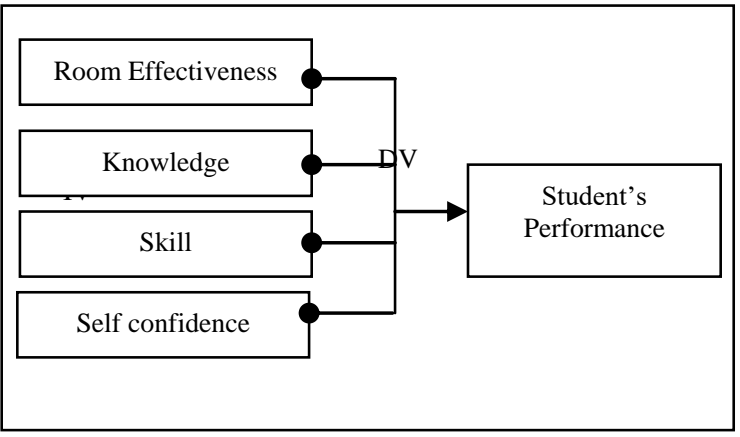

\section{E. Significance of the Study}

Currently, the coffee industry has revolved rapidly and become a global phenomenon. Due to that, it is now a trend for one to work as a barista although it is quite costly to get all the skills and knowledge in coffee preparation. In conjunction to that, this innovation is utilized for students of Hotel Operation Program to master another skill which is in demand and preparing them to be competitive in the job market. Besides that, with this innovation, the institution can be set up as a Centre of Excellence for coffee training, catering for all community colleges in Malaysia.

\section{LITERATURE REVIEW}

\section{A. Community College}

The division of Technical and Vocational Education (TAVED) under The Ministry of Higher Education was established in 1964 [2]. The function of this division was to promote the technical and vocational education in Malaysia. However, in October 1995, TAVED was changed to the Department of Technical Education [2]. From this department, the management of Community College was established to enculcate the life long learning education. The function Community College is to prepare well trained technical workforce to the nation. The learning concept in the Community College focuses on the hands on experience than theory with the ration of 75:25. There many module oferred such as automotive, accounting, business, building structure, agroculture and many more including Food and Beverage for Hotel Operation sectors.

\section{B. Food and Beverage Module}

This module is one of the modules offered by Sungai Petani Community College. The module aims to give exposure and critical understanding for students on food and beverages operation as well as its roles in the hospitality industry. The students learn about food and beverage setting, their roles and responsibilites, the decorations of food and beverages outlets and types of cutleries used. The module takes two years to be completed and the students need to comply with the requirements stated for them to obtain the Certificate of Hotel Operation [3]

According to "Reference [4]" beverage serving is the second learning area in which students are exposed to the types of hot and cold beverages as well as the steps or method in handling them correctly based on the standard operating procedure.

\section{Competency}

"Reference [5]" explains that competency is a form of knowledge, skill and capability of handling something that allows one to carry out a task excellently. On the other hand competency is defined as an ability or capability [6]. Hence, to be more competitive and give benefit the organization, competency must apply generic skills, human behaviors, observation and knowledge [6]. "Reference [7]" stated that competency cannot be separated from personal traits and professional skills. "Reference [8]" agreed that both characteristics are related and depended to each other in the tasks completion process. Competency is measured based on the work performance. "Reference [6]" suggested that there are three factors contributing to the maximum success of organization, work demand and individuals. Competency evaluation is conducted through various approaches such as observation, instructional supervision, capability and knowledge assessment, portfolio and self-evaluation [9]. In conclusion, the approaches applied for this study involved self-evaluation, and instructional supervision. These approaches are claimed to be more consistent in focusing to specific tasks and evaluating the competency levels [6].

\section{Methodology}

The approach used in this case study was a quantitative. The sample was semester two students of Hotel Operation that have completed the catering and beverages module. 30 students participated in answering the questionnaires distributed. The research instrument used in this study was a self-completed questionnaire and all respondents were required to complete a set of questionnaires, comprising three sections. Each section contains all elements that are related to the performance of students on food and beverages catering module at Sungai Petani Community College. The language used was Malay language as to make it easier for the respondents to complete the questionnaires and the evaluation scale used was 5 points likert scale. It is more reliable and accurate as it can provide larger scale of data compared to other types of evaluation scales, especially in measuring attitudes and opinions from different aspects [10].

\section{RESEARCH FINDINGS}

This study involved 30 respondents; $60 \%(n=18)$ were females and $40 \%(n=12)$ were males. This shows that the hotel operation industry is dominated by females and this field is a top choice for females to further their studies. In terms of the facilities in the Mock Barista Room, the data analysis in Table I shows the respondents agreed that the learning environment is suitable and conducive for them $(M=4.40)$. Next, the design concept and interior design are aligned with the industrial needs $(M=4.80)$. Besides that, the respondents believed that the use of light and colours in the room are suitable for teaching and learning activities $(M=4.56)$. The respondents also agreed that the arrangement of equipment is aligned with the industrial needs with the mean $(M=4.50)$. In conclusion, the use of equipment in the room is complete and suitable with the module taught. 
TABLE II: THE MEAN SCORE FOR FACILITIES IN MOCK BARISTA ROOM

\begin{tabular}{|c|c|c|c|c|c|}
\hline & $\mathrm{N}$ & Minimum & Maximum & Mean & Std. Deviation \\
\hline The learning environment is suitable and condusive. & 30 & 4.00 & 5.00 & 4.4000 & .49827 \\
\hline $\begin{array}{l}\text { The design concept and interior design are aligned with the } \\
\text { industrial needs. }\end{array}$ & 30 & 4.00 & 5.00 & 4.8000 & .40684 \\
\hline $\begin{array}{l}\text { The use of light and colours are suitable for teaching and } \\
\text { learning activities. }\end{array}$ & 30 & 4.00 & 5.00 & 4.5667 & .50401 \\
\hline $\begin{array}{l}\text { The arrangement of equipment is aligned with the industrial } \\
\text { needs. }\end{array}$ & 30 & 4.00 & 5.00 & 4.5000 & .50855 \\
\hline $\begin{array}{l}\text { The use of complete equipment that is suitable with the } \\
\text { module taught. } \\
\text { Valid N (listwise) }\end{array}$ & 30 & 4.00 & 5.00 & 4.6333 & .49013 \\
\hline
\end{tabular}

\section{Indicator:}

1. Strongly disagree 2. Disagree 3. Unsure 4.Agree 5. Strongly agree

TABLE III: THE MEAN SCORE FOR STUDENTS’ KNOWLEDGE

\begin{tabular}{|c|c|c|c|c|c|}
\hline & $\mathrm{N}$ & Minimum & Maximum & Mean & Std. Deviation \\
\hline $\begin{array}{l}\text { This module can increase my knowledge } \\
\text { in coffee barista }\end{array}$ & 30 & 4.00 & 5.00 & 4.6000 & .49827 \\
\hline $\begin{array}{l}\text { This module helps me to know the right } \\
\text { method for grinding coffee beans }\end{array}$ & 30 & 4.00 & 5.00 & 4.7333 & .44978 \\
\hline $\begin{array}{l}\text { This module increases my knowledge in } \\
\text { identifying types of coffee beans used. }\end{array}$ & 30 & 4.00 & 5.00 & 4.7000 & .46609 \\
\hline $\begin{array}{l}\text { This module helps me to identify the } \\
\text { equipment used for coffee making. }\end{array}$ & 30 & 4.00 & 5.00 & 4.7667 & .43018 \\
\hline $\begin{array}{l}\text { This module increases my knowledge on } \\
\text { the importance of cleanliness and safety } \\
\text { while operating the espresso machine and } \\
\text { grinder machine }\end{array}$ & 30 & 4.00 & 5.00 & 4.6333 & .49013 \\
\hline $\begin{array}{l}\text { The module helps me to identify the } \\
\text { correct temperature for coffee beans } \\
\text { extraction (brewing process) }\end{array}$ & 30 & 4.00 & 5.00 & 4.7000 & .46609 \\
\hline $\begin{array}{l}\text { The module helps me to identify the } \\
\text { correct temperature for heating the milk } \\
\text { (frothing milk) }\end{array}$ & 30 & 4.00 & 5.00 & 4.6667 & .47946 \\
\hline $\begin{array}{l}\text { This module helps me to identify the } \\
\text { correct technique in compacting the } \\
\text { ground coffee (tamping technique) in the } \\
\text { portafilter }\end{array}$ & 30 & 4.00 & 5.00 & 4.7667 & .43018 \\
\hline $\begin{array}{l}\text { This module helps me to identify the } \\
\text { correct technique in preparing coffee with } \\
\text { designs (coffee art) } \\
\text { Valid N (listwise) }\end{array}$ & 30 & 3.00 & 5.00 & 4.6000 & .56324 \\
\hline
\end{tabular}

Indicator:

1. Strongly disagree 2. Disagree 3 . Unsure 4.Agree 5. Strongly agree

TABLE IV: THE MEAN SCORE FOR STUDENTS' SKILLS

\begin{tabular}{|c|c|c|c|c|c|}
\hline & $\mathrm{N}$ & Minimum & Maximum & Mean & Std. Deviation \\
\hline $\begin{array}{l}\text { This module helps me to apply the right } \\
\text { technique in preparing coffee beverages }\end{array}$ & 30 & 4.00 & 5.00 & 4.6333 & .49013 \\
\hline $\begin{array}{l}\text { This module helps me to apply the } \\
\text { cleanliness and safety criteria in the coffee } \\
\text { making process }\end{array}$ & 30 & 4.00 & 5.00 & 4.7000 & .46609 \\
\hline $\begin{array}{l}\text { This module helps me to improve my } \\
\text { skills in grinding coffee beans using } \\
\text { different coffee grinder }\end{array}$ & 30 & 4.00 & 5.00 & 4.8000 & .40684 \\
\hline $\begin{array}{l}\text { This module helps me to increase my skills } \\
\text { in compacting the ground coffee (tamping } \\
\text { technique) }\end{array}$ & 30 & 4.00 & 5.00 & 4.5667 & .50401 \\
\hline $\begin{array}{l}\text { This module helps me to increase my skills } \\
\text { in using coffee and espresso machine } s\end{array}$ & 30 & 4.00 & 5.00 & 4.6000 & .49827 \\
\hline $\begin{array}{l}\text { This module helps me to increase my skills } \\
\text { in milk heating (frothing or steam milk) }\end{array}$ & 30 & 4.00 & 5.00 & 4.7667 & .43018 \\
\hline $\begin{array}{l}\text { This module helps me to increase my skills } \\
\text { in designing patterns using the free } \\
\text { pouring techniques } \\
\text { Valid N (listwise) }\end{array}$ & 30 & 4.00 & 5.00 & 4.6333 & .49013 \\
\hline
\end{tabular}

Indicator:

1. Strongly disagree 2. Disagree 3. Unsure 4.Agree 5. Strongly agree

From the aspect of effectiveness towards students' knowledge, the statistical analysis shows that the majority of respondents agreed that the module helps them to identify the correct temperature for coffee beans extraction (brewing process $)(M=4.70)$ as well as during the milk heating process (milk frothing) ( $M=4.66)$. Besides that, the respondents also believed that the module helps them to identify the correct technique in compacting the ground coffee (tamping technique) using the porta filter $(M=4.76)$. In addition to that, they also learned that this module helps them to identify the 
correct technique in preparing coffee with designs (coffee arts) $(M=4.60)$. The details are as follows:-

From the aspect of students' skills, the research findings show the majority of respondents agreed that the coffee barista module has improved their skills in the coffee making field. They believed that the module has improved their skills in practising the right technique for coffee making procedures $(M=4.63)$. Besides that, they also believed that the module has increased their knowledge on the importance of cleanliness and safety procedures during the coffee making process $(M=4.70)$. The respondents were also confident that the module has helped them to enhance their skills as they use different coffee grinders $(M=4.80)$ as well as improving their skills in compacting the ground coffee (tamping technique) $(M=4.56)$ besides the skills acquired in using the coffee and espresso machines $(M=4.60)$. In addition to that, the respondents believed that the module has improved their skills in heating the milk (frothing or steam milk) $(M=4.76)$. Hence, their coffee making skill in using the free pouring technique has also improved $(M=4.63)$ as detailed in Table IV below:-

In terms of the improvement of students' self-confidence, the data analysis on the effectiveness of module shows that the respondents were confident in completing the tasks given in more organized manners $(M=4.50)$. Besides that, they believed that they have seen improvement in the flowing of ideas and imaginations for the process of developing coffee arts $(M=4.43)$. They also believed that they are more confident in preparing the coffee beverages according to given module's objectives $(\mathrm{M}=4.36)$. In general, the respondents agreed that after completing the module, their knowledge in the coffee industry has increased $(\mathrm{M}=4.50)$. The details are as follows, in Table IV.

TABLE V: THE MEAN SCORE FOR STUdENTS' SELF CONFIDENCE

\begin{tabular}{|c|c|c|c|c|c|}
\hline & $\mathrm{N}$ & Minimum & Maximum & Mean & $\begin{array}{c}\text { Std. } \\
\text { Deviation }\end{array}$ \\
\hline $\begin{array}{l}\text { My skills have } \\
\text { improved }\end{array}$ & 30 & 4.00 & 5.00 & 4.5333 & .50742 \\
\hline $\begin{array}{l}\text { I can manage all } \\
\text { tasks given better }\end{array}$ & 30 & 3.00 & 5.00 & 4.5000 & .57235 \\
\hline $\begin{array}{l}\text { My ideas in } \\
\text { creating arts are } \\
\text { increasing }\end{array}$ & 30 & 3.00 & 5.00 & 4.4333 & .62606 \\
\hline $\begin{array}{l}\text { I can prepare } \\
\text { coffee beverages } \\
\text { according to the } \\
\text { given objectives of } \\
\text { the module }\end{array}$ & 30 & 2.00 & 5.00 & 4.3667 & .66868 \\
\hline $\begin{array}{l}\text { My knowledge in } \\
\text { the coffee field has } \\
\text { improved } \\
\text { Valid N (listwise) }\end{array}$ & 30 & 3.00 & 5.00 & 4.5333 & .57135 \\
\hline
\end{tabular}

Indicator:

1. Strongly disagree 2. Disagree 3. Unsure 4.Agree 5. Strongly agree

The statistic analysis towards the effectiveness of students' performance shows that the respondents were confident to display the safety and cleanliness techniques in coffee making $(M=4.43)$. They were also confident that they can identify types and techniques in preparing coffee beverages $(M=4.46)$ as well as able to prepare coffee latte $(M=4.43)$. The respondents were also assertive that they can differentiate types of coffee beverages in the market $(M=4.53)$ and they were also confident that they can prepare coffee beverages like espresso dan cappuccino with the correct technique $(M=4.76)$. Besides that, the respondents can differentiate the microform between coffee latte dan cappuccino $(M=4.43)$ and the task to prepare coffee beverages can be completed according to the time given $(M=4.50)$. Details are in Table V;

TABLE VI: THE MEAN SCORE FOR STUDENT's PERFORMANCE

\begin{tabular}{|c|c|c|c|c|c|}
\hline & $\mathrm{N}$ & Minimum & Maximum & Mean & $\begin{array}{c}\text { Std. } \\
\text { Deviation }\end{array}$ \\
\hline $\begin{array}{l}\text { I can show the } \\
\text { safety techniques } \\
\text { and practise } \\
\text { cleanliness in } \\
\text { preparing coffee }\end{array}$ & 30 & 3.00 & 5.00 & 4.4333 & .56832 \\
\hline $\begin{array}{l}\text { I can identify types } \\
\text { and techniques in } \\
\text { prepring coffee } \\
\text { beverages }\end{array}$ & 30 & 3.00 & 5.00 & 4.4667 & .57135 \\
\hline $\begin{array}{l}\text { I can prepare } \\
\text { coffee latte }\end{array}$ & 30 & 4.00 & 5.00 & 4.4000 & .49827 \\
\hline $\begin{array}{l}\text { I can differentiate } \\
\text { types of coffee } \\
\text { beverages }\end{array}$ & 30 & 2.00 & 5.00 & 4.5333 & .68145 \\
\hline $\begin{array}{l}\text { I can prepare } \\
\text { coffee beverages } \\
\text { like espresso and } \\
\text { cappuccino using } \\
\text { the right } \\
\text { techniques }\end{array}$ & 30 & 3.00 & 5.00 & 4.7667 & .57775 \\
\hline $\begin{array}{l}\text { I can differentiate } \\
\text { the mocroform } \\
\text { between coffee } \\
\text { latte and } \\
\text { cappuccino }\end{array}$ & 30 & 4.00 & 5.00 & 4.4333 & .50401 \\
\hline $\begin{array}{l}\text { I can prepare the } \\
\text { coffee beverages } \\
\text { within the time } \\
\text { stipulated } \\
\text { Valid N (listwise) }\end{array}$ & 30 & 3.00 & 5.00 & 4.5000 & .62972 \\
\hline
\end{tabular}

Indicator:

1. Strongly disagree 2. Disagree 3. Unsure 4.Agree 5. Strongly agree

\section{DISCUSSION, RECOMMENDATION AND CONCLUSION}

The findings of this study show positive feedback from all respondents in terms of the facilities provided in the "Mock Barista Room"; the respondents agreed that the room provides suitable and conducive learning experience. The ambience and interior design of the room are also outstanding and functional according to the industrial needs. Besides, the use of appropriate lighting and colours also supports the effective teaching and learning mode. In addition to that, the decoration of facilities and equipment is also aligned with the requirement of the industry and the equipment used is complete and suitable with the module learnt for students' professional development. The respondents believed and were confident that all of these factors are essential for effective teaching and learning environment.

Furthermore, the effectiveness of this module can be measured through three factors such as improvement in their knowledge, skills and self-confidence. The majority of respondents agreed that this module has successfully increased their knowledge for coffee barista. The module also assists them in understanding the correct methods and techniques for coffee making and latte arts skills that fulfil 
the requirements of industry as well as enable them to be competent in the field. All these three aspects have shown positive improvement and obviously the students' psychomotor performance will also improve.

In conclusion, the approach taken by the researchers in the setting up of Mock Barista Room at Sungai Petani Community College is a good start for everyone. It is aligned with the main objective in providing the students with correct and consistent procedures for coffee making as required by the industry. This can also provide opportunity for students to venture into a new field of career as a Coffee Barista because this career is in demand now in Malaysia.

In addition, the institution can develop the mock barista room to a training centre; the "Centre of Excellence for Coffee Training", serving for all community colleges in Malaysia. Sungai Petani Community College can be the resource centre in the coffee barista field as not all higher institutions have coffee barista training centre. It can also elevate the image in the industry whereby the lecturers and students can benefit the training with industry for competency enhancement. Moreover, the institution can make collaboration with the related suppliers or training providers in coffee industry for lecturers' skills enhancement and "Coffee Art" acquisition.

\section{REFERENCES}

[1] R. E. Hughes, "Skill or diploma? The potential influence of skill-based pay systems on sources of skills acquisition and degree programs," Journal Vocational Education, vol. 52, no. 4, pp. 179-183, 2003.

[2] Malaysia Government, Tenth Malaysia Plan 2010-2015, Government Press, Malaysia, 2010.

[3] Community College Education Department, Curriculum Guidelines Certificate in Hotel Operation, Restricted document, pp. 2-5, 2010.

[4] Community College Education Department, Curriculum Guidelines Certificate in Hotel Operation, Restricted document, pp. 1-5, 2014.

[5] V. Vathanopas and J. Thaingam, "Competency requirements for effective job performance in Thai public sector," Contemporary Management Research, vol. 3, no. 1, pp. 45-70, 2007.
[6] R. E. Boyatzis, "Competencies in the twenty-first century," Journal of Management Development, vol. 27, no. 1, pp. 5-12, 2008.

[7] V. Jauhari, "Competencies for a career in the hospitality industry: An Indian perspective," International Journal of Contemporary Hospitality Management, vol. 18, no. 2, pp. 123- 134, 2006.

[8] C. Levy-Leboyer, "La gestion des competences," Les Editiond Organisation, Paris, 1996.

[9] D. Bartram, "The great eight competencies: Acriterion-centric approach to validation," Journal of Applied Psychology, vol. 90,pp. 1185-1203, 2005.

[10] W. W. Cooper, Introduction to Data Envelopment Analysis and Its Use: With DEA-Solver, United State, Springer, 2006.

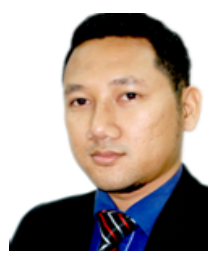

Muhd Aminuddin Bin Azizan was born in Alor Setar, Kedah, Malaysia in 1986. He was graduated from Universiti Teknologi MARA (UiTM), Pulau Pinang in year 2007 in diploma foodservice management and bachelor degree foodservice management (2009). He is currently a lecturer in Sungai Petani Community College, Ministry of Higher Education (MOHE).

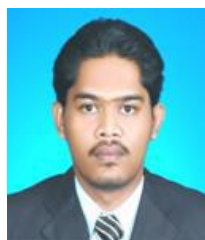

Mohd Ariff Fahmi Bin Md Noor was born in Kedah, Malaysia, in 1981. He received his diploma in foodservice management (2003) and the B.Sc (Hons) foodservice management (2005) from MARA University of Technology (UiTM) Shah Alam, Malaysi. $\mathrm{He}$ is currently a lecturer in Langkawi Tourism Academy@KK Langkawi, Ministry of Higher Education (MOHE). $\mathrm{He}$ is actively involved in design and develop curriculum for Community College Education Department, Ministry of Higher Education (MOHE)

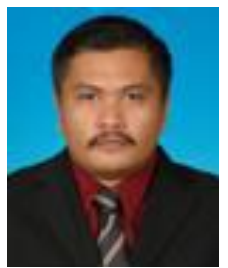

Reezlin Bin Abd Rahmanwas born in Alor Setar, Kedah, Malaysia on $18^{\text {th }}$ August 1975 . He obtained his diploma in chef training in 1996 from MARA Institute of Technology (ITM), Shah Alam,Selangor. Later on, in year 2000 he received bachelor degree in tourism management from Universiti Utara Malaysia (UUM) and master in gastronomy from Universiti Teknologi MARA (UiTM) in 2011. He is currently a senior lecturer in Sungai Petani Community College, Ministry of Higher Education. The books published are Asas Penyedian Masakan Barat (2012) and 100++ Menu Bisnes Meletup (2016). 